\title{
Modulating the Amyloidogenesis of $\alpha$-Synuclein
}

\author{
Kalkena Sivanesam and Niels H. Andersen*
}

Department of Chemistry, University of Washington, Seattle, WA 98195, USA

\begin{abstract}
Alpha-Synuclein is found in the neuronal cells but its native function is not well known. While $\alpha$-synuclein is an intrinsically disordered protein that adopts a helical conformation upon membrane binding, numerous studies have shown that oligomeric $\beta$-forms of this protein are cytotoxic. This response to misfolded species contributes to Parkinson's Disease etiology and symptoms. The resulting amyloid fibrils are an established diagnostic in Parkinson's Disease. In this review, we focus on strategies that have been used to inhibit the amyloidogenesis of $\alpha$-synuclein either by stabilizing the native state, or by redirecting the pathway to less toxic aggregates. Small molecules such as polyphenols, peptides as well as large proteins have proven effective at protecting cells against the cytotoxicity of $\alpha$-synuclein. These strategies may lead to the development of therapeutic agents that could prove useful in combating this disease.
\end{abstract}

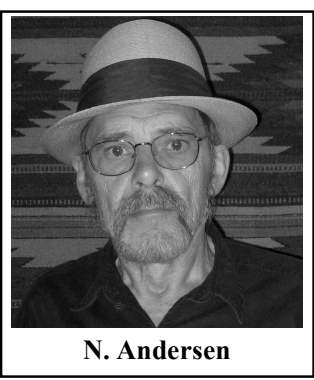

Keywords: Amyloidogenesis, antibodies, Parkinson's Disease, polyphenol, proteins, $\alpha$-synuclein.

\section{INTRODUCTION}

Parkinson's disease (PD) is a chronic and progressive disease that can be characterized by fibrillar deposits found in the brain and results in the death of dopamine producing cells. The stages of neuronal degradation have been classified [1]. One pathological feature that traditionally accompanies this disease is an intracellular inclusion body known as Lewy Bodies that has been shown to contain large amounts of a 140 amino acid protein, known as $\alpha$-synuclein [2-4]. Despite improvements in the medical treatments available to people diagnosed with PD, no real cure has been discovered, making $\alpha$-synuclein an extremely attractive target for the development of therapeutic strategies. Therefore, a significant body of research has appeared concerning this protein and its role in the development of PD. In vitro, $\alpha-$ synuclein $(\alpha$-syn) has been shown to form amyloid fibrils over a period of days to weeks. These fibrils have been detected in patients with PD in the form of plaques in the brain. Recent studies however have shown that the mature fibrils are not necessarily the cause of cell death associated with PD since autopsies have shown that there is no correlation between the amount of fibrils and the severity of PD in patients. Instead, the current hypothesis is that the soluble $\beta$-oligomers that form prior to the formation of mature fibrils are the cause of cytotoxicity [5-7]. As a result, finding a way to target the early stages of amyloidogenesis has become a crucial feature of research in this field.

The $\alpha$-syn sequence is usually subdivided into 3 parts, residues 1-60 known as the $\mathrm{N}$-terminal region, which have a predominantly helical conformation when bound to membranes [8-10], residues 61-95 that contains an NAC region which is generally regarded as the most amyloidogenic portion of the

*Address correspondence to this author at the Department of Chemistry, University of Washington, Seattle, WA 98195, USA; Tel: (206)-543-7099; Fax: (206)-685-8665; E-mail: andersen@chem.washington.edu sequence $[11,12]$ and finally, a C-terminal tail from residues 96-140, that is rich in glutamate, lacks any defined structural preferences and remains unstructured in $\beta$-oligomers [13]. The N-terminal region has been shown to form $\alpha$-helices when in contact with membranes but there are multiple postulations as to the type of helix formed. One study suggests that in solution, there are two helices formed from residues 1-100 that are interrupted by residues 43 and 44 possibly to aid in binding to the surface of the membrane [14]. A separate analysis suggests that the helix not only binds to the surface but also inserts itself into the membrane, particularly the helix formed by the NAC region from residues $70-80[15,16]$. Another study predicts that there is an extended helix encompassing the entire $\mathrm{N}$-terminal region, between residues 1-102 [17]. Studies conducted in the presence of bilayers confirm the theory of an elongated helix being formed by $\alpha$-syn [9]. However, there is evidence that the elongated helix may be in equilibrium with brokenhelix states [18]. It has also been postulated that the helices formed depend on features of the vesicle, with larger vesicles allowing $\alpha$-syn to adopt the elongated helix state and smaller diameter vesicles forcing $\alpha$-syn to adopt two antiparallel helices [19]. With regard to membrane interactions, two important, not fully answered, questions are: 1) the particularly helical state present in presynaptic terminals and 2) whether the shuffling between conformational states associated with binding to and dissociation from vesicle membranes has an effect on the aggregation of $\alpha$-syn [18].

In its native form, $\alpha$-syn undergoes a post-translational modification, acetylation at its N-terminus [20]. This modification has been suggested to be one of the ways in which native $\alpha$-syn is protected from rapid amyloidogenesis. A structural study performed on $\mathrm{N}$-terminal acetylated $\alpha$-syn showed that the presence of the acetyl group stabilizes the transient helical character of the first 9 residues of the protein. The data obtained by HSQC NMR showed that the chemical shift difference between acetylated and non- 


\section{MDVFMKGLSKAKEGVVAAAEKTKQGVAEAAGKTKEGVLYVGSKTKEGVVHGVATVAEKTK}

\section{EQVTNVGGAVVTGVTAVAQKTVEGAGSIAAATGFV}

\section{KKDQLGKNEEGAPQEGILEDMPVDPDNEAYEMPSEEGYQDYEPEA}

Fig. (1). Full sequence of $\alpha$-syndivided into the genrally recognized sections; the central NAC region is in bold.

acetylated $\alpha$-syn was confined to this region. Longer range perturbations were also observed that led to a lower propensity to form $\beta$-sheets than in non-acetylated $\alpha$-syn, confirming a stabilizing effect of the modification [21]. A comparison between the effect of acetylation on wild type $\alpha$ syn and the common familial PD mutant, A53T showed that "transient helicity" between residues 14-31 promotes amyloidogenesis in A53T while N-terminal acetylation promotes "transient helicity" in residues 1-12 and reduces amyloidogenesis. This data was confirmed using HSQC NMR that showed N-terminal acetylated wild type $\alpha$-syn and A53T $\alpha$-syn only showed different chemical shifts around the area of the mutation, indicating that the secondary structure of the N-terminus was relatively similar for both samples [22].

The role of $\alpha$-syn in the brain is not fully understood. Many possible functions have been implicated including a role in dopamine homeostasis [23], a role in neurotransmitter release regulation [24] and a role in the assembly of a soluble NSF attachment protein receptor [25]. There have also been studies that suggest conformation-specific interactions between $\alpha$-syn and mitochondrial membranes [26, 27] as well as specific proteins [28].

\section{Amyloid Formation by $\alpha$-syn}

Repeated units are an important motif within the Nterminal region of $\alpha$-syn. The presence of seven nearly conserved 11 residue pseudo-repeats that contain a shorter hexamer motif (KTKEGV) is the key example. These pseudo-repeats have been implicated in amyloidogenesis. Studies performed with shuffled $\alpha$-syn wherein the distinct pseudo-repeats are linked in a different order, showed that amyloidogenesis was decreased and the aggregates formed were amorphous, lacking the distinctive amyloid morphology [19]. Studies where the N-terminal segment of $\alpha$-syn was truncated show that the lag phase for these fragments was significantly longer than wild-type $\alpha$-syn suggesting a possible role for the N-terminal sites in amyloid nucleation [29].

The NAC region of $\alpha$-syn is so named because it was originally observed as a "non- $A \beta$ component" of the amyloid plaques found in patients with Alzheimer's disease. The consensus was that this sequence was a truncated version of $\alpha$-syn. Since then studies have shown that the core of filaments found in Lewy Body deposits found in PD patients consists of residues 31-109 [30]. Specific studies have shown that residues $68-76$ of $\alpha$-syn are in fact the minimum sequence necessary to observe amyloidogenesis in vitro as well as to demonstrate neurotoxicity in rat PC12 cells [31]. As with other amyloid fibril forming polypeptides, the kinetics of amyloidogenesis implies a nucleation-dependent polymerization with three phases: a lag phase, a growth phase, and a final plateau in fibril formation as measured by thiolflavin $\mathrm{T}(\mathrm{ThT})$ fluorescence experiments [32].

\section{Insights from Mutational Studies of $\alpha$-syn}

One characteristic of early onset PD has been the duplication or triplication of the gene locus for $\alpha$-synuclein resulting in overproduction of the protein [33, 34]. This likely reflects the concentration dependence of $\alpha$-syn amyloidogenesis [4]. Early onset PD has also been linked to a number of single site mutations of the $\alpha$-syn sequence. Some of the common mutations in familial Parkinsonism identified so far are A53T, A30P, E46K and H50Q mutations. These mutations act in different ways to enhance the toxicity of $\alpha$-syn. The A53T, E46K and H50Q mutations have been shown to increase the rate of formation of soluble oligomers in vitro [35-37]. On the other hand, the A30P mutation does not increase the rate of formation of oligomers but it does delay the transition from oligomers to insoluble fibrils; this has been proposed to be the basis for cytotoxicity of this mutation [38]. An in depth study into the structure and dynamics of the A53T and A30P mutants provided insights into the effect of these mutations on membrane binding by $\alpha$-syn. The results indicate that the A53T mutation results in no significant perturbation of the structure of $\alpha$-syn, but the A30P mutation's effect can be observed up to 30 residues on either side of the mutation. There is in fact evidence that the helical character of $\alpha$-syn in the presence of micelles is slightly increased with the presence of the A53T mutation. However, despite the A30P mutation's effect on $\alpha$-syn structure, these do not result in a significant change in micelle binding. The presence of the mutation does rearrange the two helices formed in the presence of micelles, by shifting the helix break to the proline site, the $\mathrm{N}$-terminal helix is able to reduce curvature strain and the boundary of the C-terminal helix is shifted to residue 92 . This change in $\alpha$-syn conformational preference results in a slight change in the micelle shape, but no net decrease in binding is observed [39].

A recent study by Pasanen et al. [40] probed the effect of the recently discovered familial PD mutation, A53E. Their results showed that this mutation delayed the progression of oligomers to fibrils compared to the A53T mutation and the wild type. Studies of secondary structure consequences of this mutation in the presence of membrane mimics showed that there was little or no difference between the helical character of the mutant and wild type $\alpha$-syn, as detected in helix-favoring trifluoroethanol titration experiments. However, their data did show that the membrane binding 
affinity of the mutant A53T was greatly increased compared to that of wild-type $\alpha$-syn possibly providing a basis for the pathogenesis associated with this particular mutation. In contrast, mutants A53E and A30P showed lower membrane binding affinity than wild-type $\alpha$-syn. This may result in pooling of $\alpha$-syn in certain regions favoring local amyloidogenesis processes [41].

Single site mutations of other residues within the NAC region, e.g. A78T and $\mathrm{V} 63 \mathrm{P}$, led to decreased rates of amyloidogenesis. In particular, proline mutations in this region led to a dramatic increase in lag phase [42]. A more specific study that probed the role of residues 71 to 82 within the NAC region showed that the mutation of a single residue (A76) to either a positively charged residue or a negatively charged residue resulted in significant increases to the rate of amyloidogenesis [43]. The study also showed that the NAC region formed the core of $\alpha$-syn fibrils thus confirming its pivotal role in amyloidogenesis.

\section{Role of the C-terminus in Amyloidogenesis}

The C-terminal tail of $\alpha$-syn may be involved in some interactions that modulate amyloidogenesis. Long range interactions between aromatic residues in the tail and residues within the NAC region of $\alpha$-syn have been detected $[44,45]$ and these transient interactions may inhibit the formation of fibrils. However, a study that mutated all the tyrosine residues in $\alpha$-syn to alanine showed that amyloidogenesis was completely inhibited when all 3 of the tyrosine residues in the C-terminus were mutated simultaneously, or if the single tyrosine residue in the $\mathrm{N}$ terminus, Y39 was mutated. Aggregation inhibition was also complete when only Y133 in the C-terminus was mutated [46]. These results may indicate that tyrosine residues in the $\mathrm{C}$-terminus are forming an aromatic cluster with Y39 in the $\mathrm{N}$-terminus which could be providing a shielding effect that prevents $\alpha$-syn from fibrillizing. A PRE-NMR study of $\alpha$-syn also implied that there are contacts between residues 120 140 and residues $30-100$ of $\alpha$-syn in the monomeric state [47]. This region includes the NAC region of $\alpha$-syn and the contacts with the $\mathrm{C}$-terminal tail could explain why $\alpha$-syn has a more compact structure than would be expected of a natively unfolded protein of its residue-length. Moreover, in vivo studies have shown that Lewy Bodies contain Cterminal truncated $\alpha$-syn as well as full length $\alpha$-syn [48]. In vitro studies have also confirmed that truncation of the $\mathrm{C}$ terminal leads to increased rates of amyloidogenesis [49, 50]. Inhibition studies have also shown a strong link between the C-terminal tail and inhibition. Inhibitor binding to $\alpha$-syn has been tested in a number of studies: the data suggests that some of the most potent inhibitors bind to the C-terminal tail instead of the NAC region as might otherwise be assumed [13, 51-53].

\section{Amyloidogenesis Causes Cytotoxicity}

Alpha-syn's role in causing PD likely stems from its ability to cause the death of dopamine producing neurons in the substantia nigra when $\alpha$-syn experiences amyloidogenesis $[54,55]$. The latest research shows that $\alpha$-syn's interaction with the inner membrane of the mitochondria of dopamineproducing neurons may be the cause of cell death $[56,57]$.
Research has also shown that soluble oligomers that precede the fibrils are the true cytotoxic species in most amyloidrelated diseases [4-7]. There is, however, some recent work supporting a disease-causing role for larger aggregates in the case of $\alpha$-syn [58]. The mechanism by which these, presumably $\beta$-, oligomers cause cell death is not well understood. A prominent hypothesis has been membrane pore formation [5]. Interactions between the soluble oligomers and the lipid membrane of cells could lead to the recruitment of more monomers that would lead to the formation of a channel that causes cell leakage. Yet another study postulates that rather than pore formation, the $\beta$-oligomers in fact interact with the lipid membranes and destabilize them causing them to rupture [59].

\section{Characterization of Oligomeric Forms of $\alpha$-syn}

The fibrillar structure of $\alpha$-syn is quite well characterized [60]. The structure has morphological features like amyloid fibrils from other proteins and polypeptides. The monomeric units within $\alpha$-syn fibrils, which have multiple beta-arches but no $\beta$-hairpins, are organized into parallel, intermolecular $\beta$-sheets oriented along to the fibril axis resulting in what is known as a cross- $\beta$ pattern [61]. Thioflavin T (ThT), a dye, is a common reagent used to identify this characteristic of fibrils. ThT is used due to the large increase in fluorescence that occurs upon binding to the cross $\beta$ structures [62].

While the structure of amyloid fibrils is well known, there is significant ambiguity as to the structure of the soluble oligomeric forms and determining which oligomeric form is responsible for cyctotoxicity. There is some evidence that the initial oligomers formed may be globular structures that have high percentages of $\alpha$-helical characteristics [63]. Under other conditions, ones that afford fibrils, parallel $\beta$-sheet rich, protofibril structures accumulate late in the sequence. The latter can be detected by the ThT fluorescence assay [13]. One study, however, suggests that toxic oligomers are in fact antiparallel $\beta$-sheet structures and transform to the parallel $\beta$-sheet configuration only upon forming fibrils [64].

\section{COMBATING THE TOXICITY OF A-SYN BY AMYLOIDOGENESIS INHIBITION}

Multiple strategies have been utilized in order to find agents that could reverse the cytotoxicity of $\alpha$-syn and thus serve as PD therapies. The emphasis within this account is on agents that modulate amyloidogenesis pathways. Some of the more common strategies are a) to maintain $\alpha$-syn in its random coil state and prevent it from ever forming toxic oligomers; b) to increase the rate of amyloidogenesis so that $\alpha$-syn spends very little time in the presumably toxic oligomer state and c) to direct $\alpha$-syn to form off-pathway, non-toxic aggregates. All of these strategies have yielded "inhibitors" that have shown some promise by in vitro amyloidogenesis assays and/or in cell-based studies. The challenge remains to develop drugs that will be able to penetrate the blood-brain barrier in order to effectively interact with $\alpha$-syn.

What follows is a listing of the promising lead structures for amyloidogenesis inhibition. The first three are polyphenolic antioxidants. 


\section{Small Moleculeamyloidogenesis Inhibitors}

\section{Resveratrol}

Resveratrol is a polyphenol that is found in the skin of grapes, blueberries, raspberries and mulberries and is a known antioxidant. In vivo studies have shown that resveratrol exerts neuroprotective effects on rats that have 6hydroxydopamine-induced PD, with symptoms of PD being alleviated as early as 2 days after administration [65]. It has also been shown that resveratrol is able to protect dopaminergic neurons of rats that have been administered the dopaminergic neurotoxin 1-methyl-4-phenyl-1,2,3,6tetrahydropyridine (MPTP) [66]. Its ability to protect cells from oxidative stressed caused by dopamine, in vivo, [67] and hydrogen peroxide and 6-hydroxydopamine, in vitro, made it an interesting candidate to test as a potential inhibitor of $\alpha$-syn cytotoxicity. In the only in vitro study of inhibition of $\alpha$-syn fibril formation, resveratrol was a very modest inhibitor [68] but it may share some of the activities of other polyphenols in this regard. An extensive study with SK-N-BE cells showed that resveratrol pretreatment was able to increase the viability of cells infected with A30P $\alpha$ syn by approximately $30 \%$. This effect was determined to be due to activation of a human sirtuin(SIRT1) by resveratrol since addition of sirtinol, a specific inhibitor, reverses the neuroprotective effect [69].

Resveratrol has also been shown to upregulate autophagy in cells further increasing its effectiveness as a potential neuroprotective: autophagy is down regulated in the brains of patients that have PD [70]. A study that tested PC12 cells infected with wild type, A53T and A30P $\alpha$-syn showed that the AMPK-SIRT1 autophagy pathway was upregulated in the presence of resveratrol resulting in increased cell viability. This was confirmed by the fact that an autophagy inhibitor was able to negate the effect of resveratrol as a neuroprotective agent [71]. These indirect pathways not related to $\alpha$-syn amyloidogenesis inhibition are likely responsible for the cytotoxicity modulation effects of resveratrol.

\section{EGCG}

(-)-epigallocatechin gallate is a component of green tea that has been heavily tested as an inhibitor of amyloidogenesis. This small molecule has shown promise against other amyloidogenic peptides beside $\alpha$-syn including $\mathrm{A} \beta$ and tau. More importantly, this polyphenol has been shown to redirect $\alpha$-syn misfolding to non-amyloid, spherical aggregates that are less toxic to cells [51]. The mechanism by which EGCG acts on $\alpha$-syn has been investigated. The reported data indicates that EGCG binds to $\alpha$-syn, reducing its ability to form intermolecular $\beta$-sheets and fibrils, instead redirecting it to spherical aggregates. It has also been suggested that EGCG is capable of binding to the oligomeric state of $\alpha$-syn, destabilizing it and preventing it from interacting with membranes that would ultimately lead to cytotoxicity [59]. There have also been studies of EGCG interactions with mature amyloid fibrils. In these EGCG was able to interact with preformed fibrils and convert them into spherical aggregates [72]. Rat neuronal cell studies indicate that EGCG is able to rescue the cells from "oligomer toxicity" making it a viable target for drug development.

\section{Gallic Acid}

Gallic acid is a small organic molecule found in grape skin, gallnuts, tea leaves and other plants. It is a polyphenol that has been tested against a common $\alpha$-syn mutant, A53T. The results of the study showed that gallic acid was effective in inhibiting the progress of amyloidogenesis by the mutant $\alpha$-syn which is known to have a higher rate of amyloidogenesis than wild type $\alpha$-syn [35]. This study examined the mechanism by which gallic acid interacted with A53T $\alpha$-syn: an interaction between gallic acid and unstructured A53T $\alpha$-syn which stabilizes the random coil state. A specific binding locus for this small molecule was not defined [73]. Other studies examined the effect of gallic acid on wild type $\alpha$-syn. The results suggests that at high concentrations, gallic acid is able to inhibit the formation of fibrils of $\alpha$-syn and reduce the rate of formation of oligomers. At lower concentrations however, they found that gallic acid promoted the formation of oligomers. Assays performed with the oligomers, however, indicated that they were not cytotoxic. This suggests that gallic acid also favors the formation of off-pathway non-amyloid aggregates. The effects of different phenolic compounds similar to gallic acid upon of $\alpha$-syn amyloidogenesis were also examined. The results established that there is a strong correlation between both the number of hydroxyl groups, and their placement relative to the carboxyl unit, and the ability of this class of phenols to inhibit formation of toxic oligomers by $\alpha$-syn [74].

\section{Trehalose}

Trehalose is a disaccharide (rather than polyphenol) that has proven effective at inhibiting amyloid formation by insulin and the Alzheimer-related $A \beta$ peptide $[75,76]$. This small molecule was tested against A53T $\alpha$-syn. The data showed that at low concentrations, trehalose was able to disaggregate pre-formed $\alpha$-syn fibrils and return them to random coil structures. At higher concentrations, it inhibits formation of fibrils by A53T $\alpha$-syn [77]. Trehalose was also able to induce the macroautophagy of A53T $\alpha$-syn and reduce the levels of mutant $\alpha$-syn in cells. Unfortunately the high levels of trehalose required to achieve these results were toxic to cells presenting a problem for drug development [78].

However, another study showed that trehalose was able to inhibit the overexpression of $\alpha$-syn in PC12 cells at concentrations as low as $1 \mathrm{mM}$ [79]. This result is promising because PC12 cell viability in the absence of $\alpha$-syn was not adversely affected by $10 \mathrm{mM}$ trehalose. The in vitro assays demonstrated, through the use of atomic force microscopy (AFM), that trehalose disaggregates preformed fibrils into smaller amorphous aggregates. With continued incubation with trehalose, the amorphous aggregates were broken down further to their random coil monomeric state.

\section{Ginsenosides}

Ginseng is a popular medicinal plant used in East Asia to treat a wide variety of conditions. The neuroprotective action of ginseng is due to its biologically active components, designated as ginsenosides. Three of these ginsenosides, 
namely $\operatorname{Rg} 1, \operatorname{Rg} 3$ and $\mathrm{Rb} 1$ have recently been studied as anti-amyloidogenic agents and one of them has emerged as a potent inhibitor of $\alpha$-syn amyloidogenesis. Rb1 reduces the formation of oligomers by $\alpha$-syn in vitro. In vivo, when human neuroblastoma cells were treated with aged $\alpha$-syn alone, there was a marked decrease in cell viability. However, when the cells were treated with aged $\alpha$-syn in the presence of $\mathrm{Rb} 1$, a $30 \%$ increase in cell viability was observed. The study also attempted to determine the binding locus of Rb1:it appears that Rb1 binds to, and stabilizes, oligomeric $\alpha$-syn species but does not bind to the monomeric species [80].

\section{Ceftriaxone}

Ceftriaxone is a $\beta$-lactam antibiotic that has been suggested as a potential therapeutic for multiple neurodegenerative disorders, such as Alexander's disease and cerebral ischemia. Ceftriaxone was selected based on its ability to upregulate the production of glutamate transporter subtype-1 (GLT1) which reduces the cytotoxicity of an excess of glutamate in dopaminergic neurons. This small molecule was tested in vivo and was effective in modulating the motor deficits in rats that had an induced Parkinson's disease [81]. When tested in vitro, data showed that ceftriaxone was able to completely inhibit the formation of soluble oligomers by $\alpha$-syn over the course of 11 days. A computational docking study that was performed suggested that the most likely binding locus of this molecule with $\alpha$ syn lay in the C-terminal tail, a common target for inhibitor interaction. Further studies in PC12 cells showed that ceftriaxone was able to inhibit the 6-hydroxydopamineinduced expression of $\alpha$-synuclein [82].

\section{Small Molecule Binding and Amyloid Inhibition}

A number of studies have been performed with the aim of ascertaining the binding sites of small molecule modulators of $\alpha$-syn amyloidogenesis as a step toward defining the mechanism of inhibition. In one study, five small molecules, chlorazole black E, Congo Red, lacmoid, rosmarinic acid and phthalocyanine tetrasulfate-copper complex (PcTS-Cu ${ }^{2+}$ ) were studied to determine the binding site of each molecule to $\alpha$-syn. At equimolar concentration, all 5 of these small molecules were said to interact with $\alpha$ syn in the same region, between residues 3-18 and 38-51. By observation, the common feature of all 5 molecules is the presence of negatively charged or polarized groups. It is therefore possible that these small molecules are binding at those positions due to the local abundance of lysine residues. Increasing the ratio of small molecule to $\alpha$-syn led to the discovery of secondary binding sites within the N-terminal and core region of $\alpha$-syn. However, the two generallyrecognized amyloidogenic patches, residues 66-76 and 8288 , showed no binding interactions most likely due to the fact that these stretches are extremely hydrophobic and lack sidechains that can form electrostatic interactions [83].

Lamberto et al. (2009) performed binding studies that focused upon the interaction of phthalocyanine tetrasulfate (PcTS) with $\alpha$-syn. Their results confirmed that binding of the inhibitor was taking place within the N-terminus of $\alpha$-syn between residues 3-9 and 35-41. They also observed some peak broadening in the ${ }^{15} \mathrm{~N}-\mathrm{HSQC}$ spectra, in the region of residues of 93-95. Experiments performed with $\mathrm{C}$ terminally-truncated $\alpha$-syn showed no difference in PcTS binding indicating a lack of interaction with that region. A
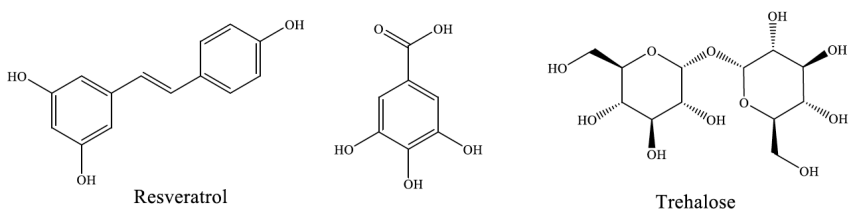

Gallic Acid

Trehalose
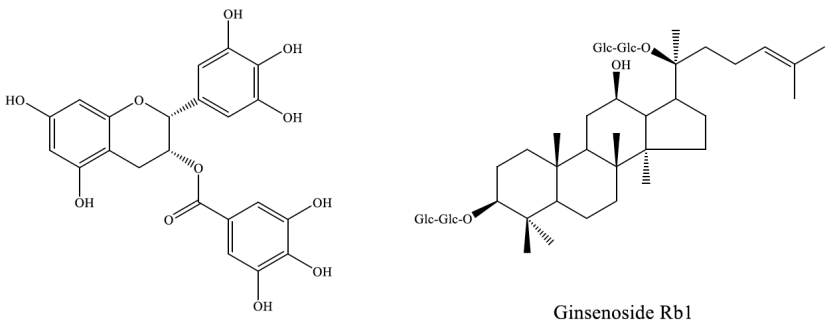

Epigallocatechin gallate (EGCG)

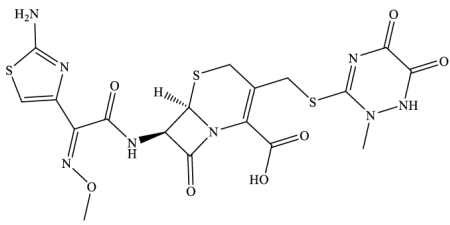

Fig. (2). Structures of the small molecule inhibitors of $\alpha$-synuclein amyloidogenesis. 
closer analysis of the binding sites revealed that the most significant peak broadening was around aromatic residues thus hinting at an interaction between PcTS and these specific residues. A mutational study of all of the aromatic residues in the N-terminus confirmed that PcTS was indeed binding to an aromatic residue, in particular, Y39, [84] reaffirming a previous hypothesis that the tyrosine residues of $\alpha$-syn play a role in amyloidogenesis [46].

EGCG and a number of related polyphenols and flavanoids have also been examined. In the case of baicalein, a flavonoid, an oxidative mechanism has been suggested. The oxidation of baicalein, affording a quinone structure, appears to be the key to amyloidogenesis inhibition. The study also suggested an interaction with the C-terminus of $\alpha$ syn since truncation of the $\mathrm{C}$-terminus completely eliminates the inhibitory effect of oxidized baicalein [85].

With regard to binding site definition, inhibitor titration studies monitored by ${ }^{15} \mathrm{~N}-\mathrm{HSQC}$ experiments using uniformly ${ }^{15} \mathrm{~N}$-labelled $\alpha$-syn have emerged as the most insightful experiments, chemical shift changes revealing the sites of binding. In the earliest study [51], it was concluded that EGCG bound predominantly to the non-amyloidogenic $\mathrm{C}$-terminal section of $\alpha$-syn. Subsequent re-interpretation of that original data and new studies suggest less specific binding [13], but another study [59] has confirmed the Cterminal location of the primary binding sites. Other polyphenols have also been examined by this method. The interaction of gallic acid and $\alpha$-syn was also studied using ${ }^{15} \mathrm{~N}$-HSQC experiments. While that study showed that the presence of gallic acid provided some protection from the peak attenuation in the N-terminus and NAC region observed over time with uninhibited $\alpha$-syn samples, the data was unable to reveal specific binding loci. In fact, the study most likely revealed, at best, a weak transient interaction between gallic acid and $\alpha$-syn [73]. A subsequent study showed no binding of gallic acid to $\alpha$-syn monomers and the authors suggested that gallic acid binds to oligomeric states of $\alpha$-syn, thus stabilizing them. Their use of size-exclusion chromatography coupled with UV scanning showed that oligomers formed in the presence of gallic acid contain gallic acid [74].

Ginsenoside Rb1 binding has also been examined by ${ }^{15} \mathrm{~N}$ -HSQC NMR. The data suggests that ginsenoside Rb1 is not inhibiting $\alpha$-syn amyloidogenesis by interacting with the monomeric state. This was confirmed by the lack of any shifts associated with the addition of inhibitor at stoichiometries of up to $6: 1$. The authors posited that binding was, in fact, occurring with the oligomeric state, thus stabilizing it and preventing it from exerting toxic effects in cells [80].

\section{Protein Binding that Prevents Aggregation: $\beta$-wrapin AS69}

One approach to preventing the formation of $\beta$-oligomers has been to stabilize the unstructured or partially structured forms of $\alpha$-syn or form species that are no longer capable of forming toxic aggregates. To this effect, a study has shown the successful synthesis of a protein that is able to selectively bind to $\alpha$-syn and prevent its transition to toxic oligomers and fibrils [86]. This binding protein is a mutated form of a previously studied protein $Z \mathrm{ZB}_{3}$, which binds to $A \beta$. The analog ( $\beta$-wrapin AS69) with G13D, V17F, I31F and L34V mutations in each of the two subunits showed a strong binding affinity for $\alpha$-syn together with a 400 -fold reduction in binding affinity for $A \beta$. The high-resolution solution state NMR structure of the complex formed between AS69 and $\alpha$-syn revealed a primary binding interface involving residues 35-56 of $\alpha$-syn. Of particular interest the bound conformation of $\alpha$-syn in this span is a $\beta$-hairpin with a ${ }^{44} \mathrm{TKEG}^{47} \beta$-turn locus. This turn locus is part of a longer loop that connects two of the $\beta$-strands in the fibrillary structure of $\alpha$-syn as determined by Vilar et al. [60]. Another study established that $\beta$-wrapin AS69, at equimolar concentrations to $\alpha$-syn, was effective as a cyctotoxicity inhibitor: the presence of $\beta$ wrapin provided complete rescue of human SH-SY5Y neuroblastoma cells from $\alpha$-syn-induced cytotoxicity [86]. The extent, if any, that a hairpin forms in this span in the absence of wrapin AS69 is not known.

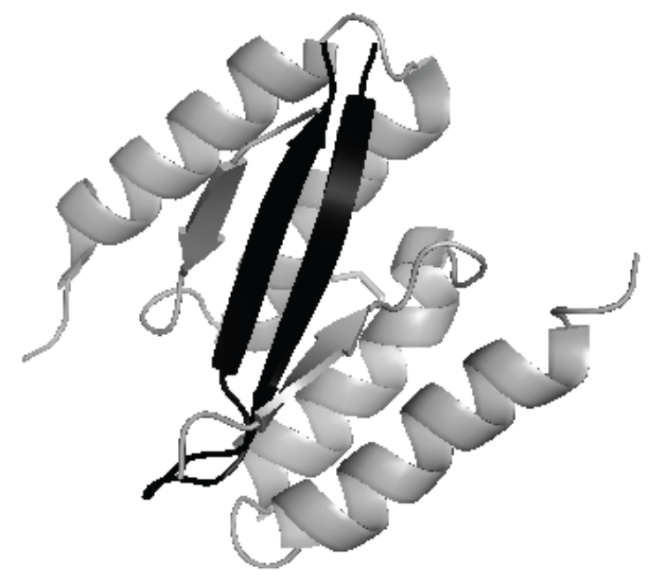

Fig. (3). The $\alpha$-syn:AS69 complex as seen in PDB 4BXL. Residues $13-58$ of the two AS69 subunits shown in grey, the observed $\beta$-hairpin residues $\left({ }^{37} \operatorname{VLYVGSK}^{43}(\beta 1){ }^{44} \mathrm{TKEG}^{47}\right.$ (turn) $\left.{ }^{48} \operatorname{VVHGVAT}^{54}(\beta 2)\right)$ of $\alpha$-syn shown in black.

\section{Antibodies: Single Chain Antibody Fragments (scFvs)}

Single chain antibody fragments have been used to target various pathogenic agents with high selectivity. An scFv that is able to target the huntingtin protein and inhibit its amyloidogenesis as well protect cells from its neurotoxic effect has been produced $[87,88]$. This concept was applied to isolate an $\mathrm{scFv}$ that was able to target $\alpha$-syn and prevent the formation of toxic oligomers. One study was able to isolate an $\mathrm{scFv}$ that had nanomolar binding affinity for monomeric $\alpha$-syn binding. In vitro tests showed that the presence of this $\mathrm{scFv}$ reduced the rate of oligomer formation by approximately a third compared to control assays. This data was confirmed via AFM [52]. A follow up study, isolated yet another $\mathrm{scFv}$, designated as D10; scFv D10 showed strong binding to monomeric $\alpha$-syn. All experiments were performed intra-cellularly and the results showed that scFv D10 was able to selectively bind to monomeric $\alpha$-syn and prevent $\alpha$-syn from transitioning to insoluble aggregates, in a dose dependent manner. The data also showed that amyloidogenesis by $\alpha$-syn leads to cell adhesion which was modulated by the presence of the scFv [53]. 
Emadi et al. employed a novel method and isolated scFv's that were able to bind only to the oligomeric species of $\alpha$-syn, thus reducing the possibility of hindering monomeric $\alpha$-syn from performing its regular function in the body. Their technique involved combining phage display technology with AFM to select an scFv that binds only to a particular target morphology of $\alpha$-syn. This technique afforded scFv D5, which showed a high affinity to oligomeric $\alpha$-syn but no binding to monomeric $\alpha$-syn. Their kinetic studies showed that, at sub-stoichiometric scFvs concentrations, $\mathrm{scFv} \mathrm{D} 5$ was able to inhibit the fibrilization of $\alpha$-syn as well as rescuing human neuroblastoma cells from the toxicity of aged $\alpha$-syn. The significance of this study is that these scFvs can be expressed intracellularly as intrabodies for potential therapeutic strategies in vivo [89].

\section{Monoclonal Antibodies}

It is known that $\alpha$-syn is not found exclusively in neuronal cells and is in fact secreted by neurons via exocytosis, having been detected in the blood and cerebrospinal fluid of both healthy individuals and PD patients $[90,91]$. A number of monoclonal antibodies for $\alpha$ syn were developed for localizing and quantitating $\alpha$-syn in the body [92]. These antibodies were later shown to aid in clearing extracellular $\alpha$-syn before it was able to exert its toxic effect on neighboring cells [93, 94]. One of these antibodies, termed Ab274, which displayed binding to the Cterminus of $\alpha$-syn, has been examined extensively. In the presence of BV12 microglial cells, this antibody promotes lysosomal 'digestion' of oligomeric and fibrillar $\alpha$-syn. The specific mechanism of action has not been elucidated but the interaction of the antibody with $\mathrm{Fc} \gamma$ receptor on the surface of microglial cells was determined to be key to the clearance of $\alpha$-syn oligomers and fibrils. The study also performed tests on transgenic $(\mathrm{tg})$ mice that overexpress human $\alpha$-syn. Upon inoculation with Ab274, the tg mice were able to complete test paradigms at a similar level to non-tg mice. However, tg mice that were inoculated with a "control $\operatorname{IgG}$ " took longer times to complete similar paradigms. The results showed that Ab274 was able to significantly reduce the transmission of $\alpha$-syn from neurons to astroglial cells. This approach may provide a therapeutic strategy because it does not interfere with the function of $\alpha$-syn within neuronal cell [95].

A similar approach was taken by Masliah et al. who identified a monoclonal antibody termed 9E4 that also recognizes the $\mathrm{C}$-terminus of $\alpha$-syn. Their passive immunization study with tg mice models that overexpress human $\alpha$-syn showed that the antibody was able to ameliorate memory and learning deficits as well as increase the clearance of $\alpha$-syn aggregates in the cortex and hippocampus of the subject. These studies showed that the antibody was able to cross the blood-brain barrier and enter the central nervous system, thus allowing it to interact with $\alpha$-syn efficiently [96].

\section{Inhibitory Peptides}

Peptides have also been examined as amyloidogenesis inhibitors and modulators of $\alpha$-syn cytotoxicity. There have been multiple approaches to the design of such peptides. The more common approach has been to model the sequence of the possible inhibitory peptides on the target system itself.

\section{Peptides as AFFITOPEs (AFFs), C-terminal Segment Mimics}

AFFITOPEs are one of the latest development in active immunization therapies. They rely on a new technology that develops short peptides capable of imprinting specific features of a previously determined antibody that is specific for a particular molecule or structure [97]. In the case of $\alpha$ syn, the antibody that was used to select peptides was specific to the oligomeric form of $\alpha$-syn. The advantages of this method lies in the fact that the peptide selected shares no sequence similarity to the native amino acid sequence of $\alpha$ syn. This prevents them from eliciting a deadly autoimmune response which has been one of the major hurdles in developing successful vaccines for $\alpha$-syn and other amyloidogenic proteins. Mandler et al. have selected and tested seven AFFs that mimic the C-terminal region of oligomeric $\alpha$-syn. Their results show that one of the AFFs, termed AFF1, is effective in selectively eliciting an immune response towards oligomeric but not monomeric $\alpha$-syn. AFF1 was also determined to be specific to $\alpha$-syn with no cross reactivity with other types of synuclein, such as $\beta$-syn. Most importantly, the AFF1 vaccination of transgenic mice was able to ameliorate the pathological behavioral and neurodegenerative symptoms of PD. This study has led to the development of a vaccine, PDO1A that is currently undergoing phase I clinical trials [98].

\section{Solubilized Segments from the $\alpha$-syn NAC Region}

Solubilized versions of the more amyloidogenic segments within this region have been particularly targeted. To this end, El-Agnaf et al. determined the minimum sequences from the $64-100$ segment of $\alpha$-syn that display peptide amyloidogenesis. A series of seven-residue peptides that span this region were synthesized and solubilized by the addition of hydrophilic residues. Peptide RGAVVTGR- $\mathrm{NH}_{2}$ emerged from this study as an effective in vitro amyloidogenesis inhibitor (based on ThT assays) when incubated with $\alpha$-syn in the ratios, 1:2, 1;1, and 2:1 [99]. This observation does not appear to have been confirmed [13].

\section{N-methylated Versions of Short a-syn Sequence Fragments}

Another approach has been to modify amyloidogenic sequence fragments by $\mathrm{N}$-methylation or the insertion of prolines. The addition of an N-methyl group decreases $\beta$-propensity and eliminates the possibility of strand association by $\mathrm{H}$-bonding, preventing the peptide from forming stable intermolecular $\beta$-sheets. N-methylation also increases the solubility of the inhibitor while reducing its susceptibility to protein degradation [100-102]. Here as well, the sequence for the inhibitor-development was selected based on a minimum sequence required to form fibrils and to display toxicity in cell culture studies. Based on studies performed with fragments from the NAC region of $\alpha$-syn and rat PC12 cells, the short sequence comprising residues ${ }^{68} \mathrm{GAVVT}^{73} \mathrm{GVTAVA}^{78}$ was selected as a cytotoxic nucleus $[31,103]$. Residue $\mathrm{G} 73$ was $\mathrm{N}$-methylated and the peptide 


$\begin{array}{ll}\text { WW2 } & \text { KKLTVW-IpGK-WITVSA } \\ \text { Cyclo-WW2 } & \text { cyclo-(PK-KLTVW-IpGK-WITVS-Ip) } \\ \text { RW-HCH-WE } & (\text { RWTTHCHRKWE })_{2} \\ \text { RY-VCI-YE } & (\text { RYTTVCIRKYE })_{2}\end{array}$

Fig. (4). Sequences of some non-homologous peptides that showed significant inhibition of $\alpha$-syn amyloidogenesis.

was tested within rat PC12 cells and determined to be nontoxic. With equimolar concentrations, the cytotoxicityof the non-methylated peptide was also markedly reduced [104]. Madine et al. (2008) examined N-methylation effects through the 71 to 82 residue span using solid-state NMR coupled with biochemical methods. A short N-methylated short peptide, VAQKTmV, corresponding to the 77-82 segment, greatly reduced the rate of amyloidogenesis when co-incubated with equimolar concentrations of $\alpha$-syn in vitro [105].

\section{Antiparallel $\beta$-sheet Peptides Lacking Sequence Homology with $\alpha$-syn}

A less common approach has been to use peptides that bear no sequence similarity to $\alpha$-syn but instead have stable $\beta$-sheet structures with edge-strands available for the association of additional strands and hydrophobic units to favor hydrophobic collapse $[13,106]$. This method, using the same very similar $\beta$-hairpin peptides, has also been successfully used to ameliorate the amyloidogenesis of the Alzheimersrelated $A \beta$ system [107] as well as the Type II Diabetes related, human amylin system [106] and shows great promise in the development of a more universal inhibitor that shows no preference for specific target systems. Both $\beta$ hairpins [106, 108-110] and disulfide-linked $\beta$-strands [13] have been examined. To date, the effective peptides in this category contain multiple aromatic residues, tryptophan and tyrosine.

The initial study, was performed with peptides that contained multiple tyrosine and/or tryptophan residues at different locations throughout a common hairpin scaffold. These had previously been tested as inhibitors of the amyloidogenesis of human pancreatic amylin. When tested as inhibitors of $\alpha$-syn amyloidogenesis, a number of the potent peptides caused precipitation of $\alpha$-syn upon or after addition of a few percent of HFIP, the aggregatory stimulus. The precipitate was visualized using Congo Red staining and transmission electron microscopy. TEM results showed that the precipitates did not have the normal morphology expected of $\alpha$-syn fibrils. Instead the interaction of the peptide with $\alpha$-syn, resulted in shorter, thicker fibrils in the case of peptides that has interacting Trp-residues and smaller, spherical aggregates in the case of the corresponding Tyr analogs [104]. These observations bear some similarity to the experiments with EGCG wherein co-incubation of high concentrations of EGCG with $\alpha$-syn led to the development of presumed off-pathway, non-amyloid aggregates that precipitate [51].
However, the point of higher interest in these studies was to find peptide inhibitors that were capable of inhibiting oligomer formation at lower concentrations. Therefore, in the follow up study that was performed [13], additional arylresidue-rich peptides with $\beta$-sheet structures were tested to determine their efficacy as inhibitors at various concentrations. The most potent inhibitors of amyloidogenesis, shown in Fig. 4, were also studied in inhibitor titration experiments monitored by ${ }^{15} \mathrm{~N}-\mathrm{HSQC}$. All of the inhibitors displayed binding shifts in the C-terminal segment of $\alpha$-syn; notably at V118, D119, D121, N122, S129, G132, and Y136. In addition, the time course of ${ }^{15} \mathrm{~N}$-HSQC peak intensities during amyloidogenesis, in the same media, in absence of inhibitors was examined. By the end of the latter experiments, when soluble $\beta$-oligomers (detected by CD) were fully formed, ThT fluorescence data indicates that these are protofibrils. At this point, the peaks in the $\mathrm{N}$-terminal and NAC region complete disappeared while C-terminal residues 104-140 remained indicating segmental motion like that of a random coil state. Even though there is evidence that the C-terminus plays some role in amyloidogenesis, it appears to be fully flexible and unstructured in the proto-fibril state [13, 60, 111-114].

Cyclo-WW2, emerged as the most potent inhibitor in this study, which served to validate the hairpin structure as the active form. Interestingly, cyclo-WW2 displays a second binding site outside of the C-terminal segment. Titration shifts were observed at residues G41, V48, H50, V52, and T54, which are not part of the classically-defined NAC region of $\alpha$-syn [12]. These same sites were the very first ones to display peak-attenuation in the ${ }^{15} \mathrm{~N}$-HSQC spectra collected in the absence of inhibitors. This is also the segment of $\alpha$ syn that is sequestered in the inhibitory AS69: $\alpha$-syn complex observed by Mirecka et al.

\section{CONCLUSIONS}

Every day more discoveries are being made concerning the role that $\alpha$-syn plays in PD etiology. Inhibitor studies have aided in uncovering much of the information about how $\alpha$-syn aggregates to form the toxic species that has been gained to date. Both peptides and small molecule polyphenols show promise as cytotoxicity inhibitors but there are still hurdles that need to be overcome before inhibitor-based treatments can be established. Among them are the lack of a proper delivery systems that can transport the drug to the target areas and the need, in most cases, for near stoichiometric dosing for effective inhibition.

Studies that focus on $\alpha$-syn itself have been able to elucidate, at least in part, the role played by the different regions of $\alpha$-syn in misfolding pathways. In particular, the region encompassing residues $37-54$ is becoming more and more prominent as a potentially crucial segment for the nucleation of both cytotoxicity and fibril formation. This makes this segment, rather than the larger NAC region, a new focus for further study that could lead to the development of therapeutic agents.

The role of the $\mathrm{C}$-terminal segment in ameliorating $\alpha$-syn amyloidogenesis is also becoming more distinct. The lack of secondary structure in this segment in fibrils coupled with its 
role in inhibiting amyloidogenesis in wild-type $\alpha$-syn makes this an interesting target for further studies. Also, the observation that many of the most effective inhibitors of aggregation, be they small molecules or peptides, binding this region shows that the dynamics and intra-molecular binding properties of this segment of $\alpha$-syn need to be examined in greater detail.

\section{CONFLICT OF INTEREST}

The authors confirm that this article content has no conflict of interest.

\section{ACKNOWLEDGEMENTS}

The initial studies at UW were supported by a grant from the NIH (GM059658-08S1). K. Sivanesam received research assistant support from NIH grant GM099889 while working on this project and review.

\section{REFERENCES}

[1] Braak, H.; Ghebremedhin, E.; Rüb, U.; Bratzke, H.; Tredici, K.D. Cell Tissue Res., 2004, 318(1), 121-134.

[2] Polymeropoulos, M.H.; Lavedan, C.; Leroy, E.; Ide, S.E.; Dehejia, A.; Dutra, A.; Pike, B.; Root, H.; Rubenstein, J.; Boyer, R.; Stenroos, E.S.; Chandrasekharappa, S.; Athanassiadou, A.; Papapetropoulos, T.; Johnson, W.G.; Lazzarini, A.M.; Duvoisin, R. C.; Di Iorio, G.; Golbe, L.I.; Nussbaum, R.L. Mutation in the Alpha-Synuclein Gene Identified in Families with Parkinson's Disease. Science, 1997, 276, 2045-2047.

[3] Spillantini, M.G.; Schmidt, M.L.; Lee, V.M.Y.; Trojanowski, J.Q.; Jakes, R.; Goedert, M. A-Synuclein in Lewy Bodies. Nature, 1997, $388,839-840$

[4] Lansbury, P.T. Evolution of Amyloid: What Normal Protein Folding May Tell Us about Fibrillogenesis and Disease. Proc. Natl. Acad. Sci. U.S.A., 1999, 96, 3342-3344.

[5] Lashuel, H.A.; Hartley, D.; Petre, B.M.; Walz, T.; Lansbury, P.T. Neurodegenerative Disease: Amyloid Pores from Pathogenic Mutations. Nature, 2002, 418, 291-291.

[6] Winner, B.; Jappelli, R.; Maji, S.K.; Desplats, P.A.; Boyer, L.; Aigner, S.; Hetzer, C.; Loher, T.; Vilar, M.; Campioni, S.; Tzitzilonis, C.; Soragni, A.; Jessberger, S.; Mira, H.; Consiglio, A.; Pham, E.; Masliah, E.; Gage, F.H.; Riek, R. In Vivo Demonstration That A-Synuclein Oligomers Are Toxic. Proc. Natl. Acad. Sci. U.S.A., 2011, 108, 4194-4199. doi: 10.1073/pnas.1100976108.

[7] Goldberg, M.S.; Lansbury Jr, P.T. Is There a Cause-and-Effect Relationship between A-Synuclein Fibrillization and Parkinson's Disease? Nat. Cell Biol., 2000, 2, E115-E119.

[8] Eliezer, D.; Kutluay, E.; Bussell, R., Jr; Browne, G. Conformational Properties of Alpha-Synuclein in Its Free and Lipid-Associated States. J. Mol. Biol., 2001, 307, 1061-1073.

[9] Jao, C.C.; Hegde, B.G.; Chen, J.; Haworth, I.S.; Langen, R. Structure of Membrane-Bound A-Synuclein from Site-Directed Spin Labeling and Computational Refinement. Proc. Natl. Acad. Sci. U.S.A., 2008, 105, 19666-19671. doi: 10.1073/pnas. 0807826105.

[10] Georgieva, E.R.; Ramlall, T.F.; Borbat, P.P.; Freed, J.H.; Eliezer, D. Membrane-Bound Alpha-Synuclein Forms an Extended Helix: Long-Distance Pulsed ESR Measurements Using Vesicles, Bicelles, and Rodlike Micelles. J. Am. Chem. Soc., 2008, 130, 12856-12857.

[11] Uversky, V.N.; Fink, A.L. Amino Acid Determinants of AlphaSynuclein Aggregation: Putting Together Pieces of the Puzzle. FEBS Lett., 2002, 522, 9-13.

[12] Pawar, A.P.; Dubay, K.F.; Zurdo, J.; Chiti, F.; Vendruscolo, M.; Dobson, C.M. Prediction of "Aggregation-Prone" and "Aggregation-Susceptible" Regions in Proteins Associated with Neurodegenerative Diseases. J. Mol. Biol., 2005, 350, 379-392.

[13] Sivanesam, K.; Byrne, A.; Bisaglia, M.; Bubacco, L.; Andersen, N. Binding Interactions of Agents That Alter A-Synuclein Aggregation. RSC Adv., 2015, 5, 11577-11590.
[14] Chandra, S.; Chen, X.; Rizo, J.; Jahn, R.; Südhof, T.C. A Broken Alpha -Helix in Folded Alpha -Synuclein. J. Biol. Chem., 2003, 278, 15313-15318.

[15] Bisaglia, M.; Tessari, I.; Pinato, L.; Bellanda, M.; Giraudo, S.; Fasano, M.; Bergantino, E.; Bubacco, L.; Mammi, S. A Topological Model of the Interaction between Alpha-Synuclein and Sodium Dodecyl Sulfate Micelles. Biochemistry, 2005, 44, 329339.

[16] Bisaglia, M.; Trolio, A.; Bellanda, M.; Bergantino, E.; Bubacco, L.; Mammi, S. Structure and Topology of the Non-Amyloid-Beta Component Fragment of Human Alpha-Synuclein Bound to Micelles: Implications for the Aggregation Process. Protein Sci. Publ. Protein Soc., 2006, 15, 1408-1416.

[17] Ramakrishnan, M.; Jensen, P.H.; Marsh, D. A-Synuclein Association with Phosphatidylglycerol Probed by Lipid Spin Labels. Biochemistry, 2003, 42, 12919-12926.

[18] Lokappa, S.B.; Ulmer, T.S. Alpha-Synuclein Populates Both Elongated and Broken Helix States on Small Unilamellar Vesicles. J. Biol. Chem., 2011, 286, 21450-21457. doi: 10.1074/jbc.M111. 224055.

[19] Rao, J.N.; Kim, Y.E.; Park, L.S.; Ulmer, T.S. Effect of Pseudorepeat Rearrangement on Alpha-Synuclein Misfolding, Vesicle Binding, and Micelle Binding. J. Mol. Biol., 2009, 390, 516-529. doi: 10.1016/j.jmb.2009.05.058.

[20] Anderson, J.P.; Walker, D.E.; Goldstein, J.M.; de Laat, R.; Banducci, K.; Caccavello, R. J.; Barbour, R.; Huang, J.; Kling, K.; Lee, M.; Diep, L.; Keim, P.S.; Shen, X.; Chataway, T.; Schlossmacher, M.G.; Seubert, P.; Schenk, D.; Sinha, S.; Gai, W.P.; Chilcote, T.J. Phosphorylation of Ser-129 Is the Dominant Pathological Modification of -Synuclein in Familial and Sporadic Lewy Body Disease. J. Biol. Chem., 2006, 281, 29739-29752.

[21] Kang, L.; Moriarty, G.M.; Woods, L.A.; Ashcroft, A.E.; Radford, S.E.; Baum, J. N-Terminal Acetylation of A-Synuclein Induces Increased Transient Helical Propensity and Decreased Aggregation Rates in the Intrinsically Disordered Monomer. Protein Sci. Publ. Protein Soc., 2012, 21, 911-917.

[22] Kang, L.; Janowska, M.K.; Moriarty, G.M.; Baum, J. Mechanistic Insight into the Relationship between N-Terminal Acetylation of A-Synuclein and Fibril Formation Rates by NMR and Fluorescence. PLoS ONE, 2013, 8, e75018.

[23] Perez, R.G.; Waymire, J.C.; Lin, E.; Liu, J.J.; Guo, F.; Zigmond, M.J. A Role for Alpha-Synuclein in the Regulation of Dopamine Biosynthesis. J. Neurosci., 2002, 22, 3090-3099. doi: 10.1016/j. neulet.2008.02.014.

[24] Nemani, V.M.; Lu, W.; Berge, V.; Nakamura, K.; Onoa, B.; Lee, M.K.; Chaudhry, F.A.; Nicoll, R.A.; Edwards, R.H. Increased Expression of Alpha-Synuclein Reduces Neurotransmitter Release by Inhibiting Synaptic Vesicle Reclustering after Endocytosis. Neuron, 2010, 65, 66-79.

[25] Burré, J.; Sharma, M.; Tsetsenis, T.; Buchman, V.; Etherton, M. R.; Südhof, T.C. Alpha-Synuclein Promotes SNARE-Complex Assembly in Vivo and in Vitro. Science, 2010, 329, 1663-1667. doi: 10.1126/science.1195227.

[26] Nakamura, K.; Nemani, V.M.; Wallender, E.K.; Kaehlcke, K.; Ott, M.; Edwards, R.H. Optical Reporters for the Conformation of Alpha-Synuclein Reveal a Specific Interaction with Mitochondria. J. Neurosci., 2008, 28, 12305-12317. doi: 10.1523/JNEUROSCI. 3088-08.2008.

[27] Nakamura, K.; Nemani, V.M.; Azarbal, F.; Skibinski, G.; Levy, J. M.; Egami, K.; Munishkina, L.; Zhang, J.; Gardner, B.; Wakabayashi, J.; Sesaki, H.; Cheng, Y.; Finkbeiner, S.; Nussbaum, R.L.; Masliah, E.; Edwards, R.H. Direct Membrane Association Drives Mitochondrial Fission by the Parkinson Disease-Associated Protein Alpha-Synuclein. J. Biol. Chem., 2011, 286, 20710-20726.

[28] Woods, W.S.; Boettcher, J.M.; Zhou, D.H.; Kloepper, K.D.; Hartman, K.L.; Ladror, D.T.; Qi, Z.; Rienstra, C.M.; George, J.M. Conformation-Specific Binding of Alpha-Synuclein to Novel Protein Partners Detected by Phage Display and NMR Spectroscopy. J. Biol. Chem., 2007, 282, 34555-34567.

[29] Zibaee, S.; Jakes, R.; Fraser, G.; Serpell, L.C.; Crowther, R.A.; Goedert, M. Sequence Determinants for Amyloid Fibrillogenesis of Human A-Synuclein. J. Mol. Biol., 2007, 374, 454-464.

[30] Miake, H.; Mizusawa, H.; Iwatsubo, T.; Hasegawa, M. Biochemical Characterization of the Core Structure of A-Synuclein Filaments. J. Biol. Chem., 2002, 277, 19213-19219. 
[31] Bodles, A.M.; Guthrie, D.J.S.; Greer, B.; Irvine, G.B. Identification of the Region of Non-A $\beta$ Component (NAC) of Alzheimer's Disease Amyloid Responsible for Its Aggregation and Toxicity. $J$. Neurochem., 2001, 78, 384-395.

[32] Fink, A.L. The Aggregation and Fibrillation of Alpha-Synuclein. Acc. Chem. Res., 2006, 39, 628-634.

[33] Mutez, E.; Leprêtre, F.; Le Rhun, E.; Larvor, L.; Duflot, A.; Mouroux, V.; Kerckaert, J.P.; Figeac, M.; Dujardin, K.; Destée, A.; Chartier-Harlin, M.C. SNCA Locus Duplication Carriers: From Genetics to Parkinson Disease Phenotypes. Hum. Mutat.2011, 32, E2079-E2090. doi: 10.1002/humu.21459.

[34] Lesage, S.; Brice, A. Parkinson's Disease: From Monogenic Forms to Genetic Susceptibility Factors. Hum. Mol. Genet.2009, 18, R48R59. doi: $10.1093 / \mathrm{hmg} / \mathrm{ddp} 012$.

[35] Conway, K.A.; Harper, J.D.; Lansbury, P.T. Accelerated in Vitro Fibril Formation by a Mutant Alpha-Synuclein Linked to EarlyOnset Parkinson Disease. Nat. Med., 1998, 4, 1318-1320.

[36] Greenbaum, E.A.; Graves, C.L.; Mishizen-Eberz, A.J.; Lupoli, M.A.; Lynch, D.R.; Englander, S.W.; Axelsen, P.H.; Giasson, B.I. The E46K Mutation in Alpha-Synuclein Increases Amyloid Fibril Formation. J. Biol. Chem., 2005, 280, 7800-7807.

[37] Ghosh, D.; Mondal, M.; Mohite, G.M.; Singh, P.K.; Ranjan, P.; Anoop, A.; Ghosh, S.; Jha, N.N.; Kumar, A.; Maji, S.K. The Parkinson's Disease-Associated H50Q Mutation Accelerates ASynuclein Aggregation in Vitro. Biochemistry, 2013, 52, 69256927. doi: 10.1021/bi400999d.

[38] Conway, K.A.; Lee, S.J.; Rochet, J.C.; Ding, T.T.; Williamson, R.E.; Lansbury, P.T. Acceleration of Oligomerization, Not Fibrillization, Is a Shared Property of Both Alpha-Synuclein Mutations Linked to Early-Onset Parkinson's Disease: Implications for Pathogenesis and Therapy. Proc. Natl. Acad. Sci. U.S.A., 2000, 97, 571-576.

[39] Ulmer, T.S.; Bax, A. Comparison of Structure and Dynamics of Micelle-Bound Human Alpha-Synuclein and Parkinson Disease Variants. J. Biol. Chem., 2005, 280, 43179-43187.

[40] Pasanen, P.; Myllykangas, L.; Siitonen, M.; Raunio, A.; Kaakkola, S.; Lyytinen, J.; Tienari, P.J.; Pöyhönen, M.; Paetau, A. A Novel A-Synuclein Mutation A53E Associated with Atypical Multiple System Atrophy and Parkinson's Disease-Type Pathology. Neurobiol. Aging, 2014, 35, 2180.e1-e5. doi: 10.1016/j.neurobiolaging.2014. 03.024 .

[41] Ghosh, D.; Sahay, S.; Ranjan, P.; Salot, S.; Mohite, G.M.; Singh, P.K.; Dwivedi, S.; Carvalho, E.; Banerjee, R.; Kumar, A.; Maji, S.K. The Newly Discovered Parkinson's Disease Associated Finnish Mutation (A53E) Attenuates A-Synuclein Aggregation and Membrane Binding. Biochemistry, 2014, 53, 6419-6421.

[42] Koo, H.J.; Lee, H.J.; Im, H. Sequence Determinants Regulating Fibrillation of Human A-Synuclein. Biochem. Biophys. Res. Commun., 2008, 368, 772-778. doi: 10.1016/j.bbrc.2008.01.140.

[43] Giasson, B.I.; Murray, I.V.; Trojanowski, J.Q.; Lee, V.M. A Hydrophobic Stretch of 12 Amino Acid Residues in the Middle of Alpha-Synuclein Is Essential for Filament Assembly. J. Biol. Chem., 2001, 276, 2380-2386.

[44] Bernadó, P.; Bertoncini, C.W.; Griesinger, C.; Zweckstetter, M.; Blackledge, M. Defining Long-Range Order and Local Disorder in Native Alpha-Synuclein Using Residual Dipolar Couplings. J. Am. Chem. Soc., 2005, 127, 17968-17969.

[45] Salmon, L.; Nodet, G.; Ozenne, V.; Yin, G.; Jensen, M.R.; Zweckstetter, M.; Blackledge, M. NMR Characterization of LongRange Order in Intrinsically Disordered Proteins. J. Am. Chem. Soc., 2010, 132, 8407-8418. doi: 10.1021/ja101645g.

[46] Ulrih, N.P.; Barry, C.H.; Fink, A.L. Impact of Tyr to Ala Mutations on Alpha-Synuclein Fibrillation and Structural Properties. Biochim. Biophys. Acta, 2008, 1782, 581-585. doi: 10.1016/j.bbadis.2008. 07.004 .

[47] Dedmon, M.M.; Lindorff-Larsen, K.; Christodoulou, J.; Vendruscolo, M.; Dobson, C.M. Mapping Long-Range Interactions in Alpha-Synuclein Using Spin-Label NMR and Ensemble Molecular Dynamics Simulations. J. Am. Chem. Soc., 2005, 127, 476-477.

[48] Baba, M.; Nakajo, S.; Tu, P.H.; Tomita, T.; Nakaya, K.; Lee, V. M.; Trojanowski, J. Q.; Iwatsubo, T. Aggregation of AlphaSynuclein in Lewy Bodies of Sporadic Parkinson's Disease and Dementia with Lewy Bodies. Am. J. Pathol., 1998, 152, 879-884
[49] Crowther, R.A.; Jakes, R.; Spillantini, M.G.; Goedert, M. Synthetic Filaments Assembled from C-Terminally Truncated A-Synuclein. FEBS Lett.1998, 436, 309-312.

[50] Murray, I.V.J.; Giasson, B.I.; Quinn, S.M.; Koppaka, V.; Axelsen, P.H.; Ischiropoulos, H.; Trojanowski, J.Q.; Lee, V.M.Y. Role of ASynuclein Carboxy-Terminus on Fibril Formation in Vitro. Biochemistry 2003, 42, 8530-8540.

[51] Ehrnhoefer, D. E.; Bieschke, J.; Boeddrich, A.; Herbst, M.; Masino, L.; Lurz, R.; Engemann, S.; Pastore, A.; Wanker, E. E. EGCG Redirects Amyloidogenic Polypeptides into Unstructured, off-Pathway Oligomers. Nat. Struct. Mol. Biol.2008, 15, 558-566. doi: $10.1038 / \mathrm{nsmb} .1437$.

[52] Emadi, S.; Liu, R.; Yuan, B.; Schulz, P.; McAllister, C.; Lyubchenko, Y.; Messer, A.; Sierks, M. R. Inhibiting Aggregation of Alpha-Synuclein with Human Single Chain Antibody Fragments. Biochemistry, 2004, 43, 2871-2878.

[53] Zhou, C.; Emadi, S.; Sierks, M. R.; Messer, A. A Human SingleChain Fv Intrabody Blocks Aberrant Cellular Effects of Overexpressed Alpha-Synuclein. Mol. Ther. J. Am. Soc. Gene Ther., 2004, 10, 1023-1031.

[54] Dawson, T. M.; Ko, H. S.; Dawson, V. L. Genetic Animal Models of Parkinson's Disease. Neuron, 2010, 66, 646-661. doi: 10.1016/j.neuron.2010.04.034

[55] Chen, L.; Xie, Z.; Turkson, S.; Zhuang, X. A53T Human ASynuclein Overexpression in Transgenic Mice Induces Pervasive Mitochondria Macroautophagy Defects Preceding Dopamine Neuron Degeneration. J. Neurosci., 2015, 35, 890-905.

[56] Chinta, S.J.; Mallajosyula, J.K.; Rane, A.; Andersen, J.K. Mitochondrial Alpha-Synuclein Accumulation Impairs Complex I Function in Dopaminergic Neurons and Results in Increased Mitophagy in Vivo. Neurosci. Lett., 2010, 486, 235-239. doi: 10.1016/j.neulet.2010.09.061.

[57] Choubey, V.; Safiulina, D.; Vaarmann, A.; Cagalinec, M.; Wareski, P.; Kuum, M.; Zharkovsky, A.; Kaasik, A. Mutant A53T AlphaSynuclein Induces Neuronal Death by Increasing Mitochondrial Autophagy. J. Biol. Chem., 2011, 286, 10814-10824. doi: 10.1074/ jbc.M110.132514.

[58] Pieri, L.; Madiona, K.; Bousset, L.; Melki, R. Fibrillar A-Synuclein and Huntingtin Exon 1 Assemblies Are Toxic to the Cells. Biophys. J., 2012, 102, 2894-2905. doi: 10.1016/j.bpj.2012.04.050.

[59] Lorenzen, N.; Nielsen, S. B.; Yoshimura, Y.; Vad, B. S.; Andersen, C. B.; Betzer, C.; Kaspersen, J. D.; Christiansen, G.; Pedersen, J. S.; Jensen, P.H.; Mulder, F.A.A.; Otzen, D.E. How Epigallocatechin Gallate Can Inhibit A-Synuclein Oligomer Toxicity in Vitro. J. Biol. Chem., 2014, jbc.M1 14.554667. doi: 10.1074/jbc.M1 14.554667.

[60] Vilar, M.; Chou, H.T.; Luhrs, T.; Maji, S.K.; Riek-Loher, D.; Verel, R.; Manning, G.; Stahlberg, H.; Riek, R. The Fold of AlphaSynuclein Fibrils. Proc. Natl. Acad. Sci. U.S.A., 2008, 105, $8637-$ 8642. doi: 10.1073/pnas.0712179105.

[61] Serpell, L.C.; Berriman, J.; Jakes, R.; Goedert, M.; Crowther, R.A. Fiber Diffraction of Synthetic A-Synuclein Filaments Shows Amyloid-like Cross-B Conformation. Proc. Natl. Acad. Sci U.S.A., 2000, 97, 4897-4902.

[62] Biancalana, M.; Koide, S. Molecular Mechanism of Thioflavin-T Binding to Amyloid Fibrils. Biochim. Biophys. Acta, 2010, 1804, 1405-1412. doi: 10.1016/j.bbapap.2010.04.001.

[63] Apetri, M.M.; Maiti, N.C.; Zagorski, M.G.; Carey, P.R.; Anderson, V.E. Secondary Structure of A-Synuclein Oligomers: Characterization by Raman and Atomic Force Microscopy. J. Mol. Biol., 2006, 355, 63-71.

[64] Celej, M.S.; Sarroukh, R.; Goormaghtigh, E.; Fidelio, G.D.; Ruysschaert, J.M.; Raussens, V. Toxic Prefibrillar A-Synuclein Amyloid Oligomers Adopt a Distinctive Antiparallel B-Sheet Structure. Biochem. J., 2012, 443, 719-726. doi: 10.1042/ BJ20111924

[65] Jin, F.; Wu, Q.; Lu, Y.F.; Gong, Q.H.; Shi, J.S. Neuroprotective Effect of Resveratrol on 6-OHDA-Induced Parkinson's Disease in Rats. Eur. J. Pharmacol., 2008, 600, 78-82. doi: 10.1016/j.ejphar. 2008.10.005.

[66] Blanchet, J.; Longpré, F.; Bureau, G.; Morissette, M.; DiPaolo, T.; Bronchti, G.; Martinoli, M.G. Resveratrol, a Red Wine Polyphenol, Protects Dopaminergic Neurons in MPTP-Treated Mice. Prog. Neuropsychopharmacol. Biol. Psychiatry, 2008, 32, 1243-1250. doi: 10.1016/j.pnpbp.2008.03.024 
[67] Lee, M.K.; Kang, S.J.; Poncz, M.; Song, K.J.; Park, K.S. Resveratrol Protects SH-SY5Y Neuroblastoma Cells from Apoptosis Induced by Dopamine. Exp. Mol. Med., 2007, 39, 376384.

[68] Caruana, M.; Högen, T.; Levin, J.; Hillmer, A.; Giese, A.; Vassallo, N. FEBS Lett., 2011, 585 (8), 1113-1120. doi: 10.1016/j.febslet. 2011.03.046.

[69] Albani, D.; Polito, L.; Batelli, S.; De Mauro, S.; Fracasso, C.; Martelli, G.; Colombo, L.; Manzoni, C.; Salmona, M.; Caccia, S.; Negro, A.; Forloni, G. The SIRT1 Activator Resveratrol Protects SK-N-BE Cells from Oxidative Stress and against Toxicity Caused by A-Synuclein or Amyloid-B (1-42) Peptide. J. Neurochem., 2009, 110, 1445-1456. doi: 10.1111/j.1471-4159.2009.06228.x.

[70] Cheung, Z.H.; Ip, N.Y. The Emerging Role of Autophagy in Parkinson's Disease. Mol. Brain, 2009, 2, 29. doi: 10.1186/17566606-2-29.

[71] Wu, Y.; Li, X.; Zhu, J.X.; Xie, W.; Le, W.; Fan, Z.; Jankovic, J.; Pan, T. Resveratrol-Activated AMPK/SIRT1/Autophagy in Cellular Models of Parkinson's Disease. Neurosignals, 2011, 19, 163-174. doi: 10.1159/000328516.

[72] Bieschke, J.; Russ, J.; Friedrich, R.P.; Ehrnhoefer, D.E.; Wobst, H.; Neugebauer, K.; Wanker, E. E. EGCG Remodels Mature AlphaSynuclein and Amyloid-Beta Fibrils and Reduces Cellular Toxicity. Proc. Natl. Acad. Sci. U.S.A., 2010, 107, 7710-7715. doi: 10.1073/pnas.0910723107.

[73] Liu, Y.; Carver, J.A.; Calabrese, A.N.; Pukala, T.L. Gallic Acid Interacts with A-Synuclein to Prevent the Structural Collapse Necessary for Its Aggregation. Biochim. Biophys. Acta, 2014, 1844, 1481-1485. doi: 10.1016/j.bbapap.2014.04.013.

[74] Ardah, M.T.; Paleologou, K.E.; Lv, G.; Abul Khair, S. B.; Kazim, A.S.; Minhas, S. T.; Al-Tel, T.H.; Al-Hayani, A.A.; Haque, M.E.; Eliezer, D.; El-Agnaf, O.M.A. Structure Activity Relationship of Phenolic Acid Inhibitors of A-Synuclein Fibril Formation and Toxicity. Front. Aging Neurosci., 2014, 6, 197.

[75] Arora, A.; Ha, C.; Park, C.B. Inhibition of Insulin Amyloid Formation by Small Stress Molecules. FEBS Lett., 2004, 564, 121125

[76] Liu, R.; Barkhordarian, H.; Emadi, S.; Park, C. B.; Sierks, M.R. Trehalose Differentially Inhibits Aggregation and Neurotoxicity of Beta-Amyloid 40 and 42. Neurobiol. Dis., 2005, 20, 74-81.

[77] Yu, W.B.; Jiang, T.; Lan, D.M.; Lu, J.H.; Yue, Z.Y.; Wang, J.; Zhou, P. Trehalose Inhibits Fibrillation of A53T Mutant AlphaSynuclein and Disaggregates Existing Fibrils. Arch. Biochem. Biophys., 2012, 523, 144-150. doi: 10.1016/j.abb.2012.04.021.

[78] Lan, D.M.; Liu, F.T.; Zhao, J.; Chen, Y.; Wu, J.J.; Ding, Z.T.; Yue, Z.Y.; Ren, H.M.; Jiang, Y.P.; Wang, J. Effect of Trehalose on PC12 Cells Overexpressing Wild-Type or A53T Mutant ASynuclein. Neurochem. Res., 2012, 37, 2025-2032. doi: 10.1007/ s11064-012-0823-0.

[79] Jiang, T.; Yu, W.B.; Yao, T.; Zhi, X.L.; Pan, L.F.; Wang, J.; Zhou, P. Trehalose Inhibits Wild-Type A-Synuclein Fibrillation and Overexpression and Protects against the Protein Neurotoxicity in Transduced PC12 Cells. RSC Adv., 2013, 3, 9500-9508

[80] Ardah, M.T.; Paleologou, K.E.; Lv, G.; Menon, S.A.; Abul Khair, S.B.; Lu, J.H.; Safieh-Garabedian, B.; Al-Hayani, A. A.; Eliezer, D.; Li, M.; El-Agnaf, O.M. A. Ginsenoside Rb1 Inhibits Fibrillation and Toxicity of Alpha-Synuclein and Disaggregates Preformed Fibrils. Neurobiol. Dis., 2015, 74, 89-101. doi: 10.1016/j.nbd.2014.11.007

[81] Leung, T.C.H.; Lui, C.N.P.; Chen, L.W.; Yung, W.H.; Chan, Y.S.; Yung, K.K.L. Ceftriaxone Ameliorates Motor Deficits and Protects Dopaminergic Neurons in 6-Hydroxydopamine-Lesioned Rats. ACS Chem. Neurosci., 2012, 3, 22-30. doi: 10.1021/cn200072h.

[82] Ruzza, P.; Siligardi, G.; Hussain, R.; Marchiani, A.; Islami, M.; Bubacco, L.; Delogu, G.; Fabbri, D.; Dettori, M. A.; Sechi, M.; Pala, N.; Spissu, Y.; Migheli, R.; Serra, P. A.; Sechi, G. Ceftriaxone Blocks the Polymerization of A-Synuclein and Exerts Neuroprotective Effects in Vitro. ACS Chem. Neurosci., 2014, 5, 30-38. doi: 10.1021/cn400149k

[83] Rao, J.N.; Dua, V.; Ulmer, T.S. Characterization of AlphaSynuclein Interactions with Selected Aggregation-Inhibiting Small Molecules. Biochemistry, 2008, 47, 4651-4656. doi: 10.1021/ bi8002378

[84] Lamberto, G.R.; Binolfi, A.; Orcellet, M.L.; Bertoncini, C.W.; Zweckstetter, M.; Griesinger, C.; Fernández, C.O. Structural and
Mechanistic Basis behind the Inhibitory Interaction of PcTS on ASynuclein Amyloid Fibril Formation. Proc. Natl. Acad. Sci. U.S.A., 2009, 106, 21057-21062. doi: 10.1073/pnas.0902603106.

[85] Meng, X.; Munishkina, L.A.; Fink, A.L.; Uversky, V.N. Molecular Mechanisms Underlying the Flavonoid-Induced Inhibition of ASynuclein Fibrillation. Biochemistry 2009, 48, 8206-8224. doi: 10.1021/bi900506b.

[86] Mirecka, E.A.; Shaykhalishahi, H.; Gauhar, A.; Akgül, S.; Lecher, J.; Willbold, D.; Stoldt, M.; Hoyer, W. Sequestration of a BHairpin for Control of A-Synuclein Aggregation. Angew. Chem. Int. Ed Engl., 2014, 53, 4227-4230. doi: 10.1002/anie.201309001.

[87] Lecerf, J. M.; Shirley, T. L.; Zhu, Q.; Kazantsev, A.; Amersdorfer, P.; Housman, D.E.; Messer, A.; Huston, J.S. Human Single-Chain Fv Intrabodies Counteract in Situ Huntingtin Aggregation in Cellular Models of Huntington's Disease. Proc. Natl. Acad. Sci. U.S.A., 2001, $98,4764-4769$.

[88] Murphy, R.C.; Messer, A. A Single-Chain Fv Intrabody Provides Functional Protection against the Effects of Mutant Protein in an Organotypic Slice Culture Model of Huntington's Disease. Brain Res. Mol. Brain Res., 2004, 121, 141-145.

[89] Emadi, S.; Barkhordarian, H.; Wang, M.S.; Schulz, P.; Sierks, M.R. Isolation of a Human Single Chain Antibody Fragment Against Oligomeric A-Synuclein That Inhibits Aggregation and Prevents A-Synuclein-Induced Toxicity. J. Mol. Biol., 2007, 368, 1132-1144.

[90] Borghi, R.; Marchese, R.; Negro, A.; Marinelli, L.; Forloni, G.; Zaccheo, D.; Abbruzzese, G.; Tabaton, M. Full Length ASynuclein Is Present in Cerebrospinal Fluid from Parkinson's Disease and Normal Subjects. Neurosci. Lett., 2000, 287, 65-67.

[91] El-Agnaf, O.M.A.; Salem, S.A.; Paleologou, K.E.; Cooper, L.J.; Fullwood, N.J.; Gibson, M.J.; Curran, M.D.; Court, J.A.; Mann, D. M.A.; Ikeda, S.I.; Cookson, M.R.; Hardy, J.; Allsop, D. ASynuclein Implicated in Parkinson's Disease Is Present in Extracellular Biological Fluids, Including Human Plasma. FASEB J., 2003, 17, 1945-1947.

[92] Lee, H.J.; Bae, E.J.; Jang, A.; Ho, D.H.; Cho, E.D.; Suk, J.E.; Yun, Y.M.; Lee, S.J. Enzyme-Linked Immunosorbent Assays for AlphaSynuclein with Species and Multimeric State Specificities. $J$. Neurosci. Methods, 2011, 199, 249-257. doi: 10.1016/j.jneumeth. 2011.05.020

[93] Desplats, P.; Lee, H.J.; Bae, E.J.; Patrick, C.; Rockenstein, E.; Crews, L.; Spencer, B.; Masliah, E.; Lee, S.J. Inclusion Formation and Neuronal Cell Death through Neuron-to-Neuron Transmission of A-Synuclein. Proc. Natl. Acad. Sci. U.S.A., 2009, 106, 1301013015. doi: 10.1073/pnas.0903691106.

[94] Lee, H.J.; Suk, J.E.; Patrick, C.; Bae, E.J.; Cho, J.H.; Rho, S.; Hwang, D.; Masliah, E.; Lee, S.J. Direct Transfer of AlphaSynuclein from Neuron to Astroglia Causes Inflammatory Responses in Synucleinopathies. J. Biol. Chem., 2010, 285, 92629272. doi: 10.1074/jbc.M109.081125.

[95] Bae, E.J.; Lee, H.J.; Rockenstein, E.; Ho, D.H.; Park, E.B.; Yang, N.Y.; Desplats, P.; Masliah, E.; Lee, S.J. Antibody-Aided Clearance of Extracellular A-Synuclein Prevents Cell-to-Cell Aggregate Transmission. J. Neurosci., 2012, 32, 13454-13469.

[96] Masliah, E.; Rockenstein, E.; Mante, M.; Crews, L.; Spencer, B.; Adame, A.; Patrick, C.; Trejo, M.; Ubhi, K.; Rohn, T. T.; MuellerSteiner, S.; Seubert, P.; Barbour, R.; McConlogue, L.; Buttini, M.; Games, D.; Schenk, D. Passive Immunization Reduces Behavioral and Neuropathological Deficits in an Alpha-Synuclein Transgenic Model of Lewy Body Disease. PLoS ONE, 2011, 6, e19338.

[97] Schneeberger, A.; Mandler, M.; Mattner, F.; Schmidt, W. AFFITOME® Technology in Neurodegenerative Diseases: The Doubling Advantage. Hum. Vaccin., 2010, 6, 948-952.

[98] Mandler, M.; Valera, E.; Rockenstein, E.; Weninger, H.; Patrick, C.; Adame, A.; Santic, R.; Meindl, S.; Vigl, B.; Smrzka, O.; Schneeberger, A.; Mattner, F.; Masliah, E. Next-Generation Active Immunization Approach for Synucleinopathies: Implications for Parkinson's Disease Clinical Trials. Acta Neuropathol., 2014, 127, 861-879.

[99] El-Agnaf, O.M.A.; Paleologou, K.E.; Greer, B.; Abogrein, A.M.; King, J.E.; Salem, S.A.; Fullwood, N.J.; Benson, F.E.; Hewitt, R.; Ford, K.J.; Martin, F.L.; Harriott, P.; Cookson, M.R.; Allsop, D. A Strategy for Designing Inhibitors of Alpha-Synuclein Aggregation and Toxicity as a Novel Treatment for Parkinson's Disease and Related Disorders. FASEB J., 2004, 18, 1315-1317. 
[100] Gordon, D.J.; Tappe, R.; Meredith, S.C. Design and Characterization of a Membrane Permeable N-Methyl Amino Acid-Containing Peptide That Inhibits Abeta1-40 Fibrillogenesis. J. Pept. Res., 2002, 60, 37-55.

[101] Kokkoni, N.; Stott, K.; Amijee, H.; Mason, J.M.; Doig, A. J. NMethylated Peptide Inhibitors of Beta-Amyloid Aggregation and Toxicity. Optimization of the Inhibitor Structure. Biochemistry, 2006, 45, 9906-9918.

[102] Adessi, C.; Frossard, M.J.; Boissard, C.; Fraga, S.; Bieler, S.; Ruckle, T.; Vilbois, F.; Robinson, S.M.; Mutter, M.; Banks, W.A.; Soto, C. Pharmacological Profiles of Peptide Drug Candidates for the Treatment of Alzheimer's Disease. J. Biol. Chem., 2003, 278, 13905-13911.

[103] Bodles, A.M.; Guthrie, D.J.S.; Harriott, P.; Campbell, P.; Irvine, G.B. Toxicity of Non-A $\beta$ Component of Alzheimer's Disease Amyloid, and N-Terminal Fragments Thereof, Correlates to Formation of B-Sheet Structure and Fibrils. Eur. J. Biochem., 2000, 267, 2186-2194.

[104] Bodles, A.M.; El-Agnaf, O.M.A.; Greer, B.; Guthrie, D.J.S.; Irvine, G.B. Inhibition of Fibril Formation and Toxicity of a Fragment of Alpha-Synuclein by an N-Methylated Peptide Analogue. Neurosci. Lett., 2004, 359, 89-93.

[105] Madine, J.; Doig, A. J.; Middleton, D.A. Design of an NMethylated Peptide Inhibitor of Alpha-Synuclein Aggregation Guided by Solid-State NMR. J. Am. Chem. Soc., 2008, 130, 78737881. doi: 10.1021/ja075356q

[106] Huggins, K.N.L.; Bisaglia, M.; Bubacco, L.; Tatarek-Nossol, M.; Kapurniotu, A.; Andersen, N. H. Designed Hairpin Peptides Interfere with Amyloidogenesis Pathways: Fibril Formation and Cytotoxicity Inhibition, Interception of the Preamyloid State. Biochemistry, 2011, 50, 8202-8212.

[107] Luo, J.; Otero, J.M.; Yu, C.H.; Wärmländer, S.K.T.S.; Gräslund, A.; Overhand, M.; Abrahams, J.P. Inhibiting and Reversing
Amyloid-B Peptide (1-40) Fibril Formation with Gramicidin S and Engineered Analogues. Chem. Weinh. Bergstr. Ger., 2013, 19, 17338-17348. doi: 10.1002/chem.201301535.

[108] Smith, T.J.; Stains, C.I.; Meyer, S.C.; Ghosh, I. Inhibition of B-Amyloid Fibrillization by Directed Evolution of a B-Sheet Presenting Miniature Protein. J. Am. Chem. Soc., 2006, 128, $14456-14457$.

[109] Andersen, N.H.; Huggins, K.N.L.; Bisaglia, M.; Bubacco, L. Designed Hairpins Modulate the Amyloidogenesis of a-Synuclein: Inhibition and Diversion to Non-Amyloid Aggregates. In Proceedings of the 31 st European Peptide Symposium; Lebl, M., Meldal, M., Jensen, K.J., Hoeg-Jensen, Eds.; European Peptide Society, 2010; pp 22-23.

[110] Byrne, A.; Bisaglia, M.; Bubacco, L.; Andersen, N.H. Probing Alpha-Synuclein Molecular Binding Sites and Their Effects on Agggregation by NMR Spectroscopy. In Proceedings of the 31st European Peptide Symposium; Kokotos, G., Constantinou, V., Matsoukas, J., Eds.; European Peptide Society, 2012; pp 546-547.

[111] Heise, H.; Hoyer, W.; Becker, S.; Andronesi, O.C.; Riedel, D.; Baldus, M. Molecular-Level Secondary Structure, Polymorphism, and Dynamics of Full-Length Alpha-Synuclein Fibrils Studied by Solid-State NMR. Proc. Natl. Acad. Sci. U.S.A., 2005, 102, 1587115876.

[112] Del Mar, C.; Greenbaum, E.A.; Mayne, L.; Englander, S.W.; Woods, V.L. Structure and Properties of A-Synuclein and Other Amyloids Determined at the Amino Acid Level. Proc. Natl. Acad. Sci. U.S.A., 2005, 102, 15477-15482.

[113] Chen, M.; Margittai, M.; Chen, J.; Langen, R. Investigation of ASynuclein Fibril Structure by Site-Directed Spin Labeling. J. Biol. Chem., 2007, 282, 24970-24979.

[114] Der-Sarkissian, A.; Jao, C.C.; Chen, J.; Langen, R. Structural Organization of A-Synuclein Fibrils Studied by Site-Directed Spin Labeling. J. Biol. Chem., 2003, 278, 37530-37535. 